\title{
Originality in UK Copyright Law: The Old "Skill and Labour" Doctrine Under Pressure
}

\author{
Andreas Rahmatian
}

Published online: 10 January 2013

(C) Max Planck Institute for Intellectual Property and Competition Law, Munich 2013

\begin{abstract}
Certainly until 2009, when Infopaq was decided, and possibly until 2012, when the CJEU handed down its decision in Football Dataco, the unanimous opinion was that in the UK a work is "original" for copyright purposes if it is the result of its author's own skill, labour, judgment and effort. The CJEU decisions in Infopaq and Football Dataco, together with Bezpecnosti and Painer in particular, are now said to have changed the general principles of copyright originality in the UK and supposedly have imported an understanding of originality from author's rights systems. This article wants to show that this view is too extreme. The CJEU rulings may lead to a slight adjustment of the UK originality definition but not to a fundamental change, and even this adjustment will not be practically relevant in most cases. Furthermore, the understanding of "originality" by the CJEU is not tantamount to the idea of originality in author's rights countries on the European continent.
\end{abstract}

Keywords Copyright $\cdot$ Neighbouring rights · Originality $\cdot$ Author's rights systems

\section{Introduction}

At least until 2009, when the Court of Justice of the European Union (CJEU) handed down its Infopaq International $v$. Danske Dagblades Forening decision, ${ }^{1}$ and possibly even until 2012, when the judgment of the CJEU in Football Dataco $v$.

${ }^{1}$ Infopaq International v. Danske Dagblades Forening [2009] ECDR 16 (Case C-5/08).

A. Rahmatian $(\bowtie)$

Mag. iur. et phil., Dr. iur. (Vienna), LL.M. (London); Solicitor (England \& Wales); Senior Lecturer in Commercial Law

School of Law, Stair Building, University of Glasgow, Glasgow G12 8QQ, UK

e-mail: Andreas.Rahmatian@glasgow.ac.uk 
Yahoo! $U K^{2}$ came out, the unanimous opinion was that in the UK for copyright purposes a work is "original", and can therefore qualify for copyright protection, if it is the result of its author's own skill, labour, judgment and effort. This "pedestrian" approach has been confirmed in numerous English cases. ${ }^{3}$ The underlying rationale for obtaining the property right of copyright is really a protection of the author's investment in the production of the work against unfair competition, especially against a competitor's free ride and his parasitical undercutting of the author's expenses by unauthorised and cheaper copying. ${ }^{4}$ Within this theoretical concept of copyright-originality, creativity, especially artistic creativity, so that the work is shaped according to the author's individual personality, plays no role. ${ }^{5}$ Furthermore, the general opinion is that in UK copyright law in fact two different levels or even qualities of originality operate, ${ }^{6}$ and the recent CJEU cases can be seen as lending support to this view. ${ }^{7}$ One is the originality rule for "usual" categories of works under copyright law (literary, dramatic, musical, artistic works), ${ }^{8}$ and the other one is the originality requirement for special types of works ${ }^{9}$ : computer programs, being literary works in law, ${ }^{10}$ and databases, which are protected by a sui generis right. ${ }^{11}$ There is even a third category of works with a special originality concept, photographs. ${ }^{12}$ This is the result of the implementation of corresponding EU Directives, ${ }^{13}$ which apparently stipulate a continental European understanding of originality ${ }^{14}$ in the way in which it is found in author's rights (droit d'auteur) countries. The CJEU judgments of

\footnotetext{
${ }^{2}$ Football Dataco Ltd and others v. Yahoo! UK Ltd and others, 1 March 2012 (Case C-604/10).

3 Most importantly, University of London Press v. University Tutorial Press [1916] 2 Ch 601, at 609-610, per Peterson J; Ladbroke (Football) v. William Hill (Football) [1964] 1 WLR 273; Independent Television Publications Ltd. v. Time Out Ltd. [1984] FSR 64. The older term "sweat of the brow" indicates labour as the relevant criterion and is too narrow today.

${ }^{4}$ Rahmatian (2011), p. 35-41.

5 Compare especially for artistic works CDPA 1988, Sec. 4(1)(a) “... irrespective of artistic quality ...". The CDPA leaves the interpretation of the term "original” to the courts, see CDPA 1988, Sec. 1(a) “... original literary, dramatic, musical or artistic works ..." (emphasis added).

${ }^{6}$ Bently and Sherman (2009), p. 93, 104, 108.

7 Infopaq, supra note 1, at para. 35, Football Dataco, supra note 2, at paras. 27-28.

8 CDPA 1988, Secs. 3 and 4. Here the originality requirement of "skill, labour and judgment" applies.

9 For these types of works (computer programs, databases and photographs) the different, and arguably higher standard of the author's own intellectual creation applies. See Bently and Sherman (2009), p. 107-109.

${ }^{10}$ CDPA 1988, Sec. 3(1)(b).

11 CDPA 1988, Sec. 3A and Copyright and Rights in Databases Regulations 1997, SI 1997/3032. Besides, databases can be protected by copyright according to the general protection criteria, CDPA 1988, Sec. 3(1)(d).

12 Term Directive 2006/116/EC, Art. 6, together with CDPA 1988, Sec. 4(1)(a): “... a ... photograph ... irrespective of artistic quality".

13 Directive 2009/24/EC of 23 April 2009 on the legal protection of computer programs (codified version); Directive 96/9/EC of 11 March 1996 on the legal protection of databases; Directive 2006/11/EC of 12 December 2006 on the term of protection of copyright and certain related rights (codified version).

14 The relevant originality provisions are in Directive 2009/24/EC (computer programs), Art. 1(3); Directive 96/9/EC (databases), Art. 3(1); Directive 2006/11/EC (term), Art. 6 (photographs).
} 
Infopaq, Bezpečnostnísoftwarová asociace, ${ }^{15}$ Painer ${ }^{16}$ and Football Dataco, having been references for a preliminary ruling in relation to the Directives on computer programs and databases and in relation to the Information Society Directive, ${ }^{17}$ made important pronouncements as to the interpretation of the originality requirement in the context of these Directives. These CJEU decisions are now said to have extended this apparent understanding of originality in author's rights systems-the work must be the result of the author's personal intellectual creation-to all areas of UK copyright law beyond the scope of the Directives at issue, thus also in relation to the "classical" works of UK copyright. ${ }^{18}$ In this way the CJEU now seems to force the UK to change its originality conception in copyright generally to bring it in line with a more author's-rights-based approach in a pan-European harmonising fashion.

It will be argued here that this is a too extreme view. The originality concepts of both the copyright system of the UK (skill and labour) and the author's rights systems (personal intellectual creation bearing the stamp of the author) are far more complex and in their iridescent appearance difficult to pinpoint. It is also doubtful that the originality requirements in the relevant Directives on special types of works really reflect the originality concept in author's rights systems in general. Furthermore, it is not entirely certain to what extent the judges of the CJEU intended any of these far-reaching changes in copyright law that some UK commentators suggest. ${ }^{19}$ At least from a more formalistic perspective, one may also assume that such a move would be outside the judges' competence.

This article will first discuss the relevant decisions of the CJEU, which are thought by some to have a fundamental impact on the notion of originality in UK copyright law as a whole. Then an overview of the UK originality concept will be given; its intrinsic inconsistencies, without any influence from the EU, will be considered. That British concept of originality will then be contrasted with the author's rights idea of originality. Different as the conceptual basis of author's rights protection and its originality requirement are, the practical results are nevertheless surprisingly similar to UK copyright law in many instances. After having discussed the reality of the operation of the originality requirement in author's rights protection in practice, the more general underlying problem of legal science and comparative law will be dealt with: how do different legal cultures interpret seemingly the same wording of a statute or of an EU Directive? The interpretation of different notions of originality across European copyright/author's rights systems illustrates this problem. These considerations are also relevant in relation to plans for a harmonisation of the whole of copyright in the EU, for

\footnotetext{
15 Bezpečnostní softwarová asociace v. Svaz softwarové ochrany v Ministerstvo kultury [2011] FSR 18 (Case C-393/09).

${ }^{16}$ Painer v. Standard Verlags GmbH, Axel Springer AG, Süddeutsche Zeitung GmbH, Spiegel-Verlag Rudolf Augstein GmbH \& Co. KG, Verlag M. DuMont Schauberg Expedition der Kölnischen Zeitung $\mathrm{GmbH} \&$ Co $K G(\mathrm{C}-145 / 10)$.

${ }^{17}$ Directive 2001/29/EC of 22 May 2001 on the harmonisation of certain aspects of copyright and related rights in the information society.

${ }^{18}$ E.g. Derclaye (2010), p. 247-251. Also Derclaye (2012).

19 Derclaye (2010), p. 247, 249 on Infopaq. Some suggestion in this regard also in: Rosati (2010), p. 542-543; and in Lee (2012), p. 293.
} 
example, in the form of a copyright code for the EU. ${ }^{20}$ Finally, a tentative outlook for the future development of the understanding of originality in UK copyright law will be attempted.

\section{The Recent Interpretation of "Originality" by the CJEU}

The important pronouncements of the ECJ (CJEU) on originality started with the Infopaq decision. ${ }^{21}$ In Infopaq, the ECJ had to decide in a preliminary ruling to Art. 2 of the Information Society Directive 2001/29 whether the storing and subsequent printing out of a text extract from an article in a daily newspaper (consisting of a search word and five preceding and five subsequent words) should be regarded as acts of reproduction that are protected. The Court held that in the present case the provisions of the EU directives in question (here especially the term "reproduction ... in part" in Art. 2 of the Directive 2001/29) do not refer expressly to the law of the Member States for their interpretation, so they have to be given an autonomous and uniform interpretation throughout the EU. This reflects in particular Recitals 6 and 21 of the Directive 2001/29, which stress-in accordance with established interpretation rules in EU law-harmonising interpretation of intellectual property rights across the EU. ${ }^{22}$ In the light of this interpretation principle of harmonising consistency, the Court went on to say that, as according to the Software Directive, the Database Directive and the Term Directive, computer programs, databases or photographs are protected by copyright only if they are original in the sense that they are their author's own intellectual creation. ${ }^{23}$ This must also apply to the prerequisites of the protection of works under Art. 2(a) of the presently discussed Information Society Directive. Therefore, a work, as referred to in this Directive, is original (and thus protected) if it is its author's own intellectual creation. This is also the case in relation to parts of a work, which cannot be treated any differently from the work as a whole. ${ }^{24}$ Newspaper articles would clearly be their author's own intellectual creation and protected as literary works under the Information Society Directive. Words as such, considered in isolation, would not seem to be an intellectual creation of the author; "it is only through the choice, sequence and combination of those words that the author may express his creativity in an original manner and achieve a result that is an intellectual creation." 25 However, the Court did not rule out that certain isolated sentences or parts of sentences may be suitable for conveying the originality of a newspaper article, so

\footnotetext{
${ }^{20}$ As proposed by the Wittem International Network Project on a European Copyright Code, available at: http://www.copyrightcode.eu/ (accessed 18 April 2012).

21 Infopaq, supra note 1.

22 Infopaq, supra note 1, at paras. 27-29. The Court rejected in this context the statement of the Austrian Government that the definition "reproduction in part" be interpreted according to the laws of the Member States.

23 Directive 2009/24/EC (computer programs), Art. 1(3); Directive 96/9/EC (databases), Art. 3(1); Directive 2006/11/EC (term), Art. 6 (photographs).

24 Infopaq, supra note 1, at paras. 35-38.

25 Infopaq, supra note 1, para. 45.
} 
that they are able to be the expression of an intellectual creation themselves. ${ }^{26}$ Whether eleven consecutive words, as in the case at issue, indeed constitute the expression of the intellectual creation of the author, is for the national court to decide. $^{27}$

The Infopaq approach was built upon in Bezpečnostní softwarová asociace, where the CJEU was asked for a preliminary ruling on the question whether a graphic user interface (which enabled communication between the computer program and the user) could be protected by copyright. ${ }^{28}$ The Court held that a graphic user interface does not enable the reproduction of a computer program, but merely constitutes one element of that program for the use of the features of that program, and therefore an interface is not the expression of a computer program and cannot be copyright-protected under Art. 1(2) of the Software Directive. But an interface may fall under subject-matter that can be protected by ordinary copyright law under the Information Society Directive: that is the case if the subject-matter is original, that is, the author's own intellectual creation, as decided by Infopaq. Accordingly, the interface can be protected, as an original work in general (though not as a computer program specifically), if it is its author's own intellectual creation. ${ }^{29}$ Whether that is indeed so in the concrete case, is for the national court to decide. The relevant criteria for the determination whether there is originality are the specific arrangement or configuration of all the components that form part of the interface, whereby this expression of the components must not be dictated by their technical function, so that the idea and the expression would become indissociable. ${ }^{30}$

In Painer, ${ }^{31}$ the CJEU followed its chosen path when it had to decide, as a preliminary matter to the question of free use and reproduction of a photograph by the press, whether a realistic portrait photograph that may only allow a very minor degree of creative freedom, can obtain copyright protection under Art. 6 of the Term Directive. The Court referred to its ruling in Infopaq, whereby subject-matter (such as a photograph) is original and protected if it is its author's own intellectual creation: in the context of a photograph that means that the intellectual creation has to reflect the author's personality, according to Recital 16 of the Term Directive. ${ }^{32}$ In case of a portrait photograph the author can make free and creative choices in several ways and at several points in its production, and can thereby "stamp the work created with his 'personal touch'". The creative freedom is by no means minor or non-existent, and so a portrait photograph can be protected by copyright as long

\footnotetext{
${ }^{26}$ Infopaq, supra note 1, para. 47.

27 Infopaq, supra note 1, para. 51.

28 Bezpečnostní, supra note 15.

29 Bezpečnostní, supra note 15, paras. 40-42, 44-46.

30 Bezpečnostní, supra note 15, paras. 48-50.

31 Painer v. Standard Verlags GmbH, Axel Springer AG, Süddeutsche Zeitung GmbH, Spiegel-Verlag Rudolf Augstein GmbH \& Co. KG, Verlag M. DuMont Schauberg Expedition der Kölnischen Zeitung GmbH \& Co KG (C-145/10), [2012] ECDR 6. See Yin Harn Lee (2012), supra note 19, at 290-293.

32 Painer, supra note 31, paras. 85-88. (Recital 16 was Recital 17 in the preceding Term Directive 93/98/ EEC.) Recital 16 however also says, "The protection of other photographs should be left to national law". On this point, see below under 4 .
} 
as it is an intellectual creation reflecting the author's personality-which has to be determined by the national courts in each concrete case. A photograph with these qualities will fall under the protection of Art. 2(a) of the Information Society Directive (protection of authors regarding the reproduction of their "work"). ${ }^{33}$

The latest step in this development is the Football Dataco decision. ${ }^{34}$ The case concerned a reference for a preliminary ruling on the interpretation of the Database Directive, especially, whether the notion of the "author's own intellectual creation" in Art. 3 of the Directive requires more than significant labour and skill from the author, and if so, what the additional requirement is. At issue was the creation of the annual fixture lists of the football leagues in England and Scotland. The process for the preparation of the football fixture lists was not purely mechanistic or deterministic; there was rather much skill and labour involved. The claimants claimed a copyright as well as a sui generis database right in these football league fixture lists. ${ }^{35}$ The Court held that such fixture lists do fulfil the definition of a database under Art. 1(2) of the Directive in principle, but even if not, copyright protection, as an independent right alongside the sui generis database right, is still available, provided, by virtue of the selection and arrangement of the content, they constitute the author's own intellectual creation. ${ }^{36}$ The notion of the author's own intellectual creation refers to the criterion of originality, as appears from Recital 16 of the Database Directive. ${ }^{37}$ This "criterion of originality is satisfied when, through the selection or arrangement of the data which it contains, its author expresses his creative ability in an original manner by making free and creative choices ... and thus stamps his "personal touch", , and here the Court refers ("by analogy") to its Infopaq, Bezpečnostni and Painer rulings. ${ }^{38}$ If the selection or arrangement of the data is an original expression of the creativity of the author of the database, copyright protection is available. However, the fact that the setting up of the database requires significant labour and skill of its author "cannot as such justify the protection of it by copyright under [the Database Directive], if that labour and that skill do not express any originality in the selection or arrangement of that data". 39 Again, the national court has to assess whether the fixture lists in question fulfil these relevant criteria of originality. ${ }^{40}$ The CJEU also held that the Database

\footnotetext{
33 Painer, supra note 31, paras. 90-95.

34 Football Dataco, supra note 2.

35 Football Dataco, supra note 2, paras. 12-20.

36 Football Dataco, supra note 2, paras. 26, 28-29.

37 Directive 96/9/EC, Recital 16: “... originality in the sense of the author's intellectual creation should be applied to determine the eligibility of the database for copyright protection, and in particular no aesthetic or qualitative criteria should be applied".

38 Directive 96/9/EC, paras. 37-38. See recently in the same spirit Football Association Premier League Ltd. et al. v. QC Leisure et al. and Karen Murphy v. Media Protection Services Ltd., CJEU 4 October 2011, joined cases (C-403/08) and (C-429/08), according to which sporting events, especially football matches, cannot be regarded as intellectual creations classifiable as works under the Copyright Directive, because they are subject to rules of the game, leaving no room for creative freedom for the purposes of copyright, see paras. 96-99.
}

39 Directive 96/9/EC, supra note 37, paras. 41-42.

40 Directive 96/9/EC, supra note 37, para. 43. 
Directive precludes national legislation, which grants databases copyright protection under conditions different from those set out in Art. 3(1) of the Directive itself (i.e. databases must be the author's own intellectual creation for obtaining protection). ${ }^{41}$

The CJEU's development of the interpretation of originality in copyright can be interpreted in the following way for the further discussion. All decisions were the result of preliminary rulings in relation to copyright Directives, which regulate special works and aspects of copyright; they were not based on a general copyright Directive with a principal and all-encompassing definition of originality, because there is at present no such general Directive. ${ }^{42}$ The different Directives (Software, Term, Database and Information Society Directives) were then read together in relation to those provisions in which the originality criterion of the "author's own intellectual creation" was stipulated for special types of works. So the general rule of EU-copyright originality (assuming the CJEU has indeed pronounced such a general rule), hinges on the special cases of databases, computer programs, ${ }^{43}$ the exploitation rights of authors in their "works", 44 and a type of photographs with a more creative input (photographic works, as understood by the Berne Convention) ${ }^{45}$ which were all applied by analogy. But such a general rule currently does not (and cannot) rest on a direct statutory EU provision on copyright originality as such. If the CJEU had intended to develop such a general rule, ${ }^{46}$ as may well be the case, it would probably have exceeded its proper role, because the rulings in relation to questions submitted for a preliminary ruling cannot extend beyond the Directives to which the questions refer; in particular, they cannot be founded on a non-existent Directive and in this way seek an implementation in the national laws of the Member States without a statutory basis in an EU-Directive or Regulation law that defines originality for copyright in general. ${ }^{47}$ In Infopaq, the Court, perhaps indicating some awareness of this problem, tried to elevate the Information Society Directive to such a comprehensive Directive, by referring to Art. 2(a) as a kind of

\footnotetext{
41 Directive 96/9/EC, supra note 37, para. 52.

42 However, one can argue that the existing Information Society Directive (Directive 2001/29/EC) leaves the door open for a more extensive application to copyright in general, see the Recitals 4, 7 and 9, and Art. 1(1).

43 Directive 96/9/EC (Database Directive) Art. 3(1); Directive 2009/24/EC (Software Directive), Art. 1(3).

44 Directive 2001/29/EC (Information Society Directive), Art. 2(a) (reproduction right).

45 Directive 2006/116/EC (Term Directive), Art. 6 and Recital 16.

46 The statement in paras. 27-28 of the Infopaq decision, supra note 1, at may be interpreted as an attempt at a broader rule: "... the need for uniform application of community law and the principle of equity require that where provisions of Community law make no express reference to the law of the Member States for the purpose of determining their meaning and scope, as is the case with art. 2 of Directive 2001/29, they must normally be given an autonomous and uniform interpretation throughout the Community." The problem is, one may argue, that there is currently no extant Community law on copyright-originality in general that can be given "autonomous and uniform interpretation".

47 On the question of the inclusion by the CJEU of other Community Law provisions beyond those cited in the reference for a preliminary ruling, see Broberg and Fenger (2010), p. 408-414. According to these authors, the CJEU shows generally some reticence in extending the scope of a reference. This cannot be said of Infopaq and the subsequent cases; furthermore, it is at least arguable that in these cases a Community Law provision appears included which does not even exist as yet (that is, a general rule on originality in copyright).
} 
general rule of originality for all works. ${ }^{48}$ In fact, Art. 2(a) talks about the protection of the reproduction right "for authors, of their works", which presupposes originality of the works in question, but does not define what originality means. National copyright statutes are often also silent as to the nature of originality and leave its definition to case law, such as the $\mathrm{UK}^{49}$ or France, ${ }^{50}$ and, from a practical perspective, in fact also Germany, despite its statutory definition of originality. ${ }^{51}$ Furthermore, the Information Society Directive, in Art. 1(2), states clearly that it shall not affect the provisions relating to the legal protection of computer programs and databases and the provisions in the Term Directive, which suggests that the Information Society Directive is not supposed to be an all-encompassing umbrella Directive, but rather a set of provisions sitting alongside the other copyright Directives. In Infopaq, the Court also referred to the fact that the Berne Convention in Art. 2(5) and (8) assumes that the protection of literary and artistic works presupposed such works as intellectual creations. ${ }^{52}$ But that means that the classical British "skill and labour" originality would be compatible, because the Berne Convention was not, and was never supposed to be, understood in such a way so as to exclude Berne membership of the UK and other countries with "skill and labour" originality. ${ }^{53}$ So an argument founded on the Berne Convention is of no assistance, nor is, as such, the invocation of the principle of the impetus in the EU towards a harmonised legal framework for copyright as a legal basis for a harmonised originality requirement. ${ }^{54}$ It is well known that, because of the different nature of copyright works and the inevitable unpredictability of case law, the originality requirements are not even consistent or harmonised within one copyright jurisdiction, and probably will never be. ${ }^{55}$ Finally, the term "own intellectual creation", which the respective Directives use, and which the CJEU seeks to deploy as perhaps a general basis for the understanding of originality in copyright across the EU, is a label that means little without an underlying body of grown case law. If the CJEU wanted to interpret the term "own intellectual creation" as a new

\footnotetext{
48 Infopaq, supra note 1, at paras. 33, 36.

49 UK: CDPA 1988, Sec. 1(1)(a): "Copyright ... subsists ... in ... original literary, dramatic, musical or artistic works", with no further definition of "original".

50 Lucas and Lucas (2006), p. 71.

51 The German Copyright Act 1965 states in Sec. 2(2) that the work must be a "personal intellectual creation". See, however, Loewenheim in: Schricker and Loewenheim (2010) "Einleitung", note 6: "Die Wendung [persönliche geistige Schöpfung] ist wenig präzise und aufschlußreich ... Klarere Konturen gewinnt sie erst durch die umfangreiche Rechtsprechung ..." (The wording [personal intellectual creation] lacks precision and is little insightful. ... It obtains clearer contours with the extensive body of case law ...). In the following the commentary on German author's rights law by Gerhard Schricker and Ulrich Loewenheim (eds.) (2010), Urheberrecht. Kommentar (München: C.H. Beck) will be cited as: [author] in: Schricker and Loewenheim (2010), Sec. _ note _ (i.e. note _ to Sec. _ of the German Act on Copyright and Related Rights (Copyright Act) (Urheberrechtsgesetz 1965). The equivalent to the "original work" in UK law is the "individual work" in German law; see Loewenheim in: Schricker and Loewenheim (2010) Sec. 2 note 23.

52 Infopaq, supra note 1, at para. 34.

53 Ricketson and Ginsburg (2005), p. 404-405 regarding Art. 2(1) of the Berne Convention.

54 So Infopaq, supra note 1, at para. 36, Football Dataco, supra note 2, at para. 48-49.

55 See below under 4.
} 
autonomous originality criterion harmonised throughout the EU and for copyright in general, not only for specific types of work, ${ }^{56}$ this could affect the originality requirements of both the copyright and the author's rights countries. ${ }^{57}$ There is good reason to believe that the criterion "own intellectual creation" is neither a copyright Common Law nor a droit d'auteur Civil Law term of art, but something different from both. It is possibly also closer to the UK copyright understanding than to the droit d'auteur idea of originality if one considers the history of the making of the Directives in which this criterion can be found. These matters will now be looked at in turn.

\section{The Principal Conceptions of Originality in UK Copyright and European Author's Rights (Droit d'auteur) Countries}

The different types of originality in copyright in Europe cannot be reduced to a quantitatively "higher" or "lower" threshold but are conceptually different qualities of originality. The traditional British conception of originality in copyright is so familiar that a brief outline will suffice. Works that originate from the author and are the product of the author's own sufficient skill, labour and effort, expenses and judgement (not necessarily all criteria at the same time) obtain copyright protection. Artistic originality or ingenuity, creativity and novelty, is irrelevant. ${ }^{58}$ The rationale of copyright protection in the UK (in the form of a property right) is the prevention of a shortcut and of a free ride on a competitor's effort and investment. The cases on originality over the last 100 years leave no doubt about this ultimate motive of copyright protection:

... it is a sound principle that a man shall not avail himself of another's skill, labour, and expense by copying the written product thereof. To quote the language of North J. in another case: "For the purposes of their own profit they desire to reap where they have not sown, and to take advantage of the labour and expenditure of the plaintiffs ... 59

Free trade does not require that one man should be allowed to appropriate without payment the fruits of another's labour, whether they are tangible or intangible. The law has not found it possible to give full protection to the intangible. But it can protect the intangible in certain states, and one of them is when it is expressed in words and print. ${ }^{60}$

\footnotetext{
56 One could read the Infopaq decision, supra note 1, at paras. 27-28 and, following on, the Football Dataco decision, supra note 2, at paras. 48-49 (for databases), in this way.

57 In the following discussion it will be shown that the changes would rather be conceptual, theoretical changes, but there would only be limited practical consequences.

58 E.g. University of London Press v. University Tutorial Press [1916] 2 Ch 601, at 609-610; Ladbroke (Football) v. William Hill (Football) [1964] 1 WLR 273, at 281-282, 287-291. There are few exceptions where artistic quality is relevant, for example with regard to works of artistic craftsmanship, CDPA 1988, Sec. 4(1)(c). Strictly speaking, the work must also be a qualifying work to obtain protection, CDPA 1988, Secs. 153 et seq., but this aspect is disregarded here.

59 Walter v. Lane [1900] AC 539, at 552, per Lord Davey.

${ }^{60}$ Ladbroke (Football) Ltd. v. William Hill (Football) Ltd. [1964] 1 WLR 273, at 290-291, per Lord Devlin.
} 
The solution accords with a reasonable view of public policy-that the sort of work done by the claimant should be encouraged. It saves others the time and trouble of recreation of near-lost works, but in no sense creates monopoly in them. If someone wants to use the claimant's short cut, they need his permission. $^{61}$

In this way, copyright protects the author's property that the author has created (i.e. the copyright work). ${ }^{62}$ This idea is in the spirit of John Locke: as a person's property is protected to protect the person's liberty, ${ }^{63}$ the person himself becomes protected through the protection of the property the person makes. Thus, the author as property maker obtains indirect protection through the direct protection of the property he has created: the copyright work protected by copyright indirectly protects its author, especially the author's economic standing. It is not (artistic) creativity, but the potential (not actual) economic value of the author's investment, skill and labour deployed in the making of a property (the copyright work) which copyright protects. ${ }^{64}$

The idea of the work having originated entirely from the author is, however, problematic: derivative works do get protection. The relevant condition for protection is that the derivative work must be the product of a material change ${ }^{65}$ when compared with the pre-existing work. Skill, labour or judgment alone in the process of copying of the pre-existing work cannot confer originality: "there must in addition be some element of material alteration or embellishment which suffices to make the totality of the work an original work." However, even a "relatively small alteration or addition qualitatively" may, if it is material, convert into an original work something which is substantially copied from an earlier work. ${ }^{66}$ Relevant is an element of choice: there must be the possibility to choose one alteration over another. With these choices the author is able to express his creative abilities, and so the author can stamp the work with his "personal touch", to use the language of the CJEU in Painer ${ }^{67}$ as regards photographs and in Football Dataco ${ }^{68}$ as regards databases. When the expression is dictated by its technical function, and therefore there is no choice and the idea and the expression merge (or become "indissociable", according to the CJEU in Bezpečnostni' softwarova ${ }^{69}$ with regard to graphic

\footnotetext{
61 Sawkins v. Hyperion [2005] EWCA Civ 365, at para. 87, per Jacob LJ.

62 Rahmatian (2011), p. 38.

63 Locke (1960 [1690]) Chap. 5, Secs 27, 35; Chap. 7, Secs 85, 87; Chap. 9, Sec. 127; Chap. 11, Sec. 138; Chap. 16, Sec. 192; Chap. 19, Sec. 222.

64 Rahmatian (2011), p. 16, 35-44, 170-174.

65 Macmillan v. Cooper (1924) 40 TLR 186, 188, at para. 17: “To secure copyright ... it is necessary that the labour, skill and capital expended should be sufficient to impart to the product some quality or character which the raw material did not possess, and which differentiates the product from the raw material".

66 Interlego A.G. v Tyco Industries Inc. [1988] RPC 343 at 371-372, per Lord Oliver.

67 Painer, supra note 16, at paras. 89-90, 92.

68 Football Dataco, supra note 2, at paras. 37-38.

69 Bezpečnostní softwarová, supra note 15, at para. 49.
} 
user interfaces), the work is not original and is not protected (the "merger doctrine" in US copyright law ${ }^{70}$ ).

Another question is the required amount of skill and labour to qualify for protection. A de minimis rule exists: it is traditionally lower in the UK than in the US. Where the work requires little effort, skill and labour and the outcome is commonplace, or, put differently, the work lacks quality of individuality able to distinguish it from mere commonplace, ${ }^{71}$ the work will not be regarded as original. But also the higher originality threshold in the US case of Feist, ${ }^{72}$ requiring a certain minimal degree of creativity, ${ }^{73}$ does not move the US from the copyright countries to the author's rights systems. The difference between the traditional approach to originality in the UK (and also Australia ${ }^{74}$ ) and the US is a quantitative one: subjectmatter of protection in both jurisdictions is the author's property which he made, only in the US the general minimum threshold for protection is higher. US academics did not see Feist as a fundamental change to the conceptual basis of US copyright law, when this decision came out. ${ }^{75}$ In US law before Feist, there existed effectively two kinds of copyright protection alongside one another already: one of "low authorship works" which have mainly the labour and investment in mind; and the other of "high authorship works" which represent not only the economic interests but also, though not predominantly, the person of the creator. Feist sides with "high authorship" protection and requires a modicum of creativity in the selection and arrangement of information in a compilation, but does not challenge the already existing principle that a subjective selection of information satisfies the minimal standard of creativity. Highly personal choice is not required; the selection only has to be the result of thoughtful evaluation and choice. ${ }^{76}$ Furthermore, if one looks at UK copyright law, one realises that the minimum threshold of originality seems to depend on the type of work, and a clear distinction between quantitative and qualitative labour that has to go into the work to turn it original cannot be made out. $^{77}$ So the originality concept is not consistent within UK copyright law itselfunderstandably, because different types of works require an individual application of general principles. There is also inconsistency even within one category of works. For example, within the group of literary works the abridgement of a text from

\footnotetext{
${ }_{70}$ Kregos v. Associated Press, 937 F.2d 700, 705 (CA-NY, 2nd Cir.1991); and already Baker v. Selden, 101 U.S. 99 (11 Otto 99). See also recently SAS Institute Inc. v. World Programming Ltd., CJEU 2 May 2012 (Case C-406/10), paras. 31, 40.

71 Cramp v. Smythson [1944] AC 329: in that case it was the compilation of commonplace information in tables in front of a diary. Similar Waylite Diary CC v. First National Bank [1993] EIPR D-242.

72 Feist Publications Inc. v. Rural Telephone Service Co Inc. 499 US 340.

73 “... the work was independently created by the author (as opposed to copied from other works), and ... it possesses at least some minimal degree of creativity. ... To be sure, the requisite level of creativity is extremely low; even a slight amount will suffice. The vast majority of works make the grade quite easily, as they possess some creative spark ...", Feist, supra note 72, at 345.

74 Telstra Corporation Ltd. v. Desktop Marketing Systems Pty Ltd. [2002] FCAFC 112.

75 See discussion in Rosati (2010), p. 533-536.

76 Ginsburg (1992), p. 340-341, 345.

77 Bently and Sherman (2009), p. 95 note 27, and p. 97 note 38.
} 
40,000 to 20,000 words for the use in schools was held not to be original, ${ }^{78}$ while the transcription of a speech by a reporter was original. ${ }^{79}$

So far, one cannot (or: need not) detect a fundamental difference between the definitions of originality by the UK courts and the CJEU, as far as the outcome is concerned; the term "own intellectual creation" of the Directives can be translated without difficulty into "originating from the author" ("own") and into "qualitative element of material alteration as a choice by the author's intellect" ("intellectual creation"). It is only likely that the level of required originality has been lifted up slightly by the CJEU in a US Feist-like manner, provided we can ascertain, for the purpose of comparison, a chief originality threshold in traditional UK copyright law in the first place. However, as already mentioned, the UK originality concept is not without contradictions and irregularities. This is not only true of its quantitative threshold, ${ }^{80}$ but also of its qualitative requirements. In some sectors of UK copyright law, especially in the area of the protection of the visual arts and (by virtue of the statute itself $^{81}$ ) of artistic craftsmanship, ${ }^{82}$ originality may in effect be assessed according to the creative-artistic input made and therefore assumes a significantly higher, and qualitatively different, level, contrary to the principal "pedestrian" originality rule. ${ }^{83}$ Inconsistencies in relation to the originality requirement are also characteristic in the area of joint authorship, particularly of musical works, where the courts sometimes require that a joint author's contribution shows significant and creative originality to qualify for joint authorship and ownership. ${ }^{84}$ This can have the curious effect that a single author may well qualify with much less individualising input. ${ }^{85}$

But all these aspects of the originality threshold are only variations of the same principle of originality in copyright systems, as becomes clear when one contrasts these with the idea of originality within the philosophical framework of author's rights laws in general. ${ }^{86}$ The heart and essence of protection of authors in an author's rights system is the author as the human being. The author is protected by

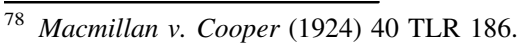

79 Walter v. Lane [1900] AC 539. This case, decided prior to the Copyright Act 1911, was held to be still good law most recently in Sawkins v. Hyperion [2005] 3 All ER 636, paras. 33 and 78. For a discussion why this analysis is arguably correct but why Walter $v$. Lane does not add anything new to the definition of originality in UK copyright law, see Rahmatian (2009), p. 579-580. Walter v. Lane remains a problematic ruling (if it remains relevant at all); see discussion by Pila (2008), p. 546-550.

${ }^{80}$ As illustrated above with the conflict between the rulings of Macmillan v. Cooper (1924) 40 TLR 186 and Walter v. Lane [1900] AC 539.

81 CDPA 1988, Sec. 4(1)(c).

${ }^{82}$ The problem of asking the courts to decide what is "artistic" is well illustrated by the unclear ruling of George Hensher v. Restawile Upholstery [1976] AC 64.

83 A further discussion of this complicated matter in Rahmatian (2011), p. 188-191.

${ }^{84}$ So especially Hadley v. Kemp [1999] EMLR 589 at 642, 648. Arnold (1999), p. 464-469.

85 Further discussion of the originality requirement in musical works of joint authorship in Rahmatian (2009), p. 570-573; Rahmatian (2011), p. 191-193.

86 Outline in English in Rahmatian (2011), p. 48-56.
} 
the author's right as a person (in its conception a kind of human right ${ }^{87}$ ) and therefore everything the author creates and which bears the features of the author's personality also obtains protection. ${ }^{88}$ The author in droit d'auteur systems is not merely a property maker: the property product the author creates (the work of the author) is indirectly protected through the author's personality protection. This is the opposite to the UK copyright idea. In the UK the author as property maker obtains indirect protection through the direct protection of the property he has created: the work protected by copyright indirectly protects its author. ${ }^{89}$ In droit d'auteur countries the author's right work is indirectly protected through the author's personality protection: in this way author's rights take account of the author's economic rights $^{90}$ (and the author's investment, skill and labour)—which are important, but not the root and cause of the protection system. ${ }^{91}$ Three principles ensue from this conceptual framework. First, the author has to be a natural author, ${ }^{92}$ statutory authors, ${ }^{93}$ or (corporate) authors under a "works made for hire" doctrine ${ }^{94}$ are ruled out in principle. ${ }^{95}$ Secondly, the personality of the author as a physical human being is protected by the moral rights, of which the right to be named as the author ("paternity/attribution right") and the right to object to derogatory treatment of the work ("integrity right") are the most important ones. 96 These moral rights are

\footnotetext{
87 The author's right is a special type of personality right, but - in its manifestation as the moral rights-a lex specialis to the general personality right, compare for Germany with its particularly strong personality rights tradition in its author's rights law, Dietz and Peukert in: Schricker and Loewenheim (2010) Vor Secs. 12 et seq. notes $14-15$.

88 Compare Vivant and Bruguière (2009), p. 21: “Le droit d'auteur ... est un droit de l'auteur sur l'idée que l'œuvre n'est jamais que la continuation de la personne ..." (original emphasis).

89 Rahmatian (2011), p. 35.

90 Compare Vivant and Bruguière (2009), p. 433; Rehbinder (2010), p. 36, on the economic interests of the author.

91 Or, one can say, in a pointed and simplifying way: in the UK, the work protects its author, in the droit d'auteur countries, the author protects his/her work.

92 E.g. France: Vivant and Bruguière (2009), p. 190-191; Germany: Loewenheim in: Schricker and Loewenheim (2010) Sec. 7 notes 1-5. The recent decision of the French Supreme Court (Cour de cassation) (1 ${ }^{\text {re }}$ civ., 22 March 2012, No. de pourvoi: 11-10132, available at: legifrance.gouv.fr, accessed 11 April 2012) which gave the owner of the author's right in a collective work (Art. L. 113-5 French Intellectual Property Code 1992) moral rights in that work, undermines the principle that the author must be a natural person, because the owner of the author's right in the collective work can be (and often is) a legal person.

93 Creators or producers (whether natural or legal persons) of entrepreneurial works: sound recordings, films (the film is a hybrid of authorial and entrepreneurial work), broadcasts, typographical arrangements, CDPA 1988, Secs. 9(2)(aa), (ab), (b) and (d). See Bently and Sherman (2009), p. 123-125.

94 US Copyright Act 1976, 17 USC § 201(b). Compare the same rationale in Sec. 21 of the old UK Copyright Act 1911, regarding photographs (the owner and investor in the negative of the photograph was author).

95 Compare Germany which rejects the idea of a work-made-for-hire concept emphatically, Loewenheim in: Schricker and Loewenheim (2010) Sec. 7 note 4, Rojahn in: Schricker and Loewenheim (2010) Sec. 43 notes 37-39 (duty to grant a licence to employer but employee retains authorship and ownership of the author's right). This principle is not always followed strictly in all author's rights countries; see e.g. the Dutch Author's Rights Act 1912, Arts. 6 and 8 with a kind of works-made-for-hire rule.

96 See, at the international level, Art. $6^{\text {bis }}$ of the Berne Convention (Paris text 1971).
} 
integral to the author's rights protection system, ${ }^{97}$ and not just an addendum without being a constituent element within the copyright system, as is the case in the UK. ${ }^{98}$ Thirdly, as the personality protection of the author extends to what emanates from the author as a person, the work must bear traces of the author's personality to deserve protection. The work must therefore bear the stamp or imprint of the author's personality (so France, "l'empreinte de la personnalité de l'auteur" ${ }^{99}$ ), or be a personal intellectual creation (so Germany, "persönliche geistige Schöpfungen" ${ }^{100}$ ). The individuality of the work is the source of its protection: ${ }^{101}$ this is the concept of originality in droit d'auteur countries. Not only must the work originate from the author, it must also have been shaped by the author's individual distinct personality; it must not just be commonplace, a work that could be attributed to anyone. ${ }^{102}$ Historically, this protection philosophy has its root ultimately in Kant ${ }^{103}$ and Hegel, ${ }^{104}$ although this intellectual link is rather tenuous from the practical viewpoint of doctrinal law. ${ }^{105}$

One can see that, even if the term "own intellectual creation" in the EU Directives were adopted as the originality test in the UK and also interpreted in line with the originality notions in the author's rights systems, ${ }^{106}$ this would not make the UK a droit d'auteur country. The deciding element is not whether originality is only defined as pedestrian skill, labour and effort, or whether some limited creative input in the making of the work is required, similar to the Feist test in the US for originality. In both cases, these types of originality are pre-requisites, albeit at a different level, for the making of the copyright-property: in the centre of protection is the property created, not its creator. Only if the natural person of the author were at the centre of protection (and the work and its economic exploitation were notionally ${ }^{107}$ incidental to the author's personality protection), the UK would be a droit d'auteur country. This entails that the moral rights would be the backbone of

\footnotetext{
97 Lucas and Lucas (2006), p. 343; Germany: Rehbinder (2010), p. 16-17, 157-158; Rigamonti (2006), p. 355-356.

98 CDPA 1988, Secs. 77 et seq. On this detached nature of the moral rights in relation to the rest of the copyright system, see Cornish (1989), p. 449: "an extreme form of dualism" and: "The British moral rights ... are not part of copyright”. See also Rahmatian (2011), p. 47, 237-239.

99 Lucas and Lucas (2006), p. 73; Vivant and Bruguière (2009), p. 163; Binctin (2010), p. 47.

100 German Copyright Act 1965, Sec. 2(2). Loewenheim in: Schricker and Loewenheim (2010) Sec. 2 notes 8, 11, 18; Rehbinder (2010), p. 33.

101 Compare Rehbinder (2010), p. 28, for Germany.

102 E.g. see for France, Lucas and Lucas (2006), p. 72; Binctin (2010), p. 47. For Germany, Rehbinder (2010), p. 68.

103 Kant (1785), p. 403-417.

104 Hegel (1991) Secs. 65-66, 68-69, p. 95-97, 98-101.

105 Rahmatian (2011), p. 77-86 (Hegel), p. 86-90 (Kant).

106 This additional criterion is important, because in the UK the term "own intellectual creation" technically applies already within the realm of the implemented Directives (e.g. Software Directive, Art. $1(3))$.

107 One should not adhere to the idealistic notion that the economic exploitation of author's rights in reality is merely a side issue. Also, in author's rights countries, the economic exploitation is often the only really relevant aspect for practical purposes.
} 
the whole copyright protection system without which it would fall apart conceptually. ${ }^{108}$ It is not the level of originality required, but the quality of originality resulting from the intellectual framework behind it which determines whether there is "copyright" or "author's right" originality. These are qualitatively two different concepts, irrespective of whether one or the other may lead to a higher originality threshold in a given case. ${ }^{109}$ It also becomes clear in this context that "own intellectual creation" is not, on its own, a droit d'auteur notion of originality, but rather neutral and chameleonic.

\section{The Reality About Originality in Droit d'auteur Countries}

The last argument, that the originality requirement in the Directives "own intellectual creation" is not per se a droit d'auteur notion, becomes particularly obvious if one considers that the Directives in which this originality requirement appears enacted the protection of works which were, and are still perceived as, strange elements within the author's rights systems: e.g. non-artistic photographs, computer programs and databases. Their protection has as its core an investment protection, thus a British, not a continental European notion of protection. The British copyright system with its low originality standard, geared towards the protection of the potential economic value of someone's investment (in a broad sense), needed these Directives the least.

In theory, the concept of originality in author's rights countries has primarily not the manufacturer of intellectual goods or "property" in mind, but the creative artist. But the reality is entirely different. Author's rights countries were faced with the fact that most — and especially most commercially valuable-works have no artistic merit. Pragmatic jurisprudence in author's rights countries acknowledged that originality cannot be assessed according to artistic quality, and it is not. In droit d'auteur countries, novelty or artistic merit is irrelevant, and there is no requirement for a high level of individuality of the work. ${ }^{110}$ Similar to the UK, in author's rights countries there is also the phenomenon of different standards of originality for different types of works. ${ }^{11}$ This applies within the categories of the classical authorial literary and artistic works themselves (whether "novel" or derivative), and between these and the "new" types of works, such as computer programs and databases. $^{112}$

\footnotetext{
108 The US, with their higher originality standard according to Feist, have only a rudimentary moral rights regime which applies to the visual arts only; see US Copyright Act 1976, 17 USC § 106A, and Rigamonti (2006), p. 405.

109 Compare, from a French viewpoint, Lucas and Lucas (2006), p. 74.

110 France: Lucas and Lucas (2006), p. 81-82; Germany: Rehbinder (2010), p. 29-31, Loewenheim in: Schricker and Loewenheim (2010), Sec. 2 notes 24-25.

111 Lucas and Lucas (2006), p. 83; Binctin (2010), p. 46: "l'originalité est un concept fuyant ..."; Rehbinder (2010), p. 68-69; Loewenheim in: Schricker and Loewenheim (2010), Sec. 2 note 32.

112 This vast and detailed area goes well beyond the scope of this article. Further discussion e.g. in Lucas and Lucas (2006), p. 87-123; Vivant and Bruguière (2009), p. 167-182; Loewenheim in: Schricker and Loewenheim (2010), Sec. 2 notes 75-217, Sec. 3 notes 1-43, Sec. 4 notes 5-57.
} 
Furthermore, for practical purposes the originality level is generally greatly lowered by what is called in German law the concept of "kleine Münze"113 (similar as "petite monnaie" in France, ${ }^{114}$ in translation: "small change"). According to this protection concept, works of practical use and commonplace appearance with little individuality obtain protection, such as telephone directories, recipe books, catalogues, reproduction of artworks, and especially also compilations in general. ${ }^{115}$ Thus works are protected under this notion that have been described as "des auvres du langage de caractère technique et des compilations utilitaires dans lesquels la marque de la personnalité de l'auteur n'est pas évidente." ${ }^{116}$ Computer programs, databases, compilations and photographs with low creative input are all regarded as instances of the application of the "kleine Münze" principle. ${ }^{117}$ This means such works are in principle eligible for author's rights protection, not just for protection under a neighbouring right or under unfair competition rules against parasitical free ride. However, the originality of these works can only be a normatively established originality, not a real one, because an individual stamp of the author can hardly be detected with works of that kind. This situation has prompted commentators to ask whether the concept of originality in an author's rights system is only "une notion vide". ${ }^{118}$ In Germany, it has frequently been suggested that one should abolish the "kleine Münze" concept and move such works into the protection sphere of German unfair competition law, ${ }^{119}$ especially under what is called "ergänzender Leistungsschutz" (essentially an ancillary protection against free riding, copying and acts which would typically fall into the area of passing off in the UK). ${ }^{120}$

The understanding of originality is also mirrored in the characteristic division of author's rights laws into author's rights proper for works of some level of originality, and neighbouring rights for works where the commercial investment protection is more relevant. An important example for the present discussion is the work category of photographs in German author's rights law. As a broad definition, the difference between "author's rights" ("Urheberrechte") and "neighbouring rights" ("Leistungsschutzrechte", "Verwandte Schutzrechte") is that the former protect a newly formed work in which the individual spirit of the author as its creator manifests itself, while the latter protect endeavours that discover, represent and realise an already extant work of the mind. ${ }^{121}$ Photographs can be protected as photographic works, a separate category of works ("Lichtbildwerke") if they are

\footnotetext{
113 Rehbinder (2010), p. 69.

114 Lucas and Lucas (2006), p. 75.

115 See Rehbinder (2010), p. 69; Loewenheim in: Schricker and Loewenheim (2010), Sec. 2 notes 26, 39; Lucas and Lucas (2006), p. 79, for examples of cases. Rahmatian (2011), p. 57, for an outline in English of the kleine Münze concept.

116 Lucas and Lucas (2006), p. 75.

117 France: Lucas and Lucas (2006), p. 78, 80; Germany: Rehbinder (2010), p. 31, 69; Loewenheim in Schricker and Loewenheim (2010), Sec. 2 note 39, with specific reference to the EU Directives prescribing the "kleine Münze" protection in Germany for software, databases and photographs.

118 Vivant and Bruguière (2009), p. 160-161.

119 Rehbinder (2010), p. 31, 58, 69.

120 Section 4(9) of the German Act Against Unfair Competition (UWG) 2010.

121 Rehbinder (2010), p. 298, for the definition.
} 
personal intellectual creations (thus passing the German originality test) ${ }^{122}$ or, if not, they can still be protected under a neighbouring right as mere photographs ("Lichtbilder"). ${ }^{123}$ (A similar normative distinction exists between cinematographic works and mere films). ${ }^{124}$ The main difference between these two types of photographs is a perhaps narrower scope of protection ${ }^{125}$ and a shorter protection period for photographs under the neighbouring right (50 years from first appearance instead of 70 years pma). In practice, the distinction between these two categories is often difficult, because "authorial" photographs can benefit from the "kleine Münze" concept for their protection under author's rights law. ${ }^{126}$ In the case of "kleine Münze" authorial photographs ("Lichtbildwerke") and "mere photographs" ("Lichtbilder"), protection based on (limited) creative originality and, on the other hand, on a neighbouring right coalesce. Thus the CJEU in Painer did not say anything new by stating that a photograph is original and protected if it is its author's own intellectual creation, that is, the intellectual creation has to reflect the author's personality. ${ }^{127}$ The CJEU's reference to Recital 16 of the Term Directive in this context underlines the fact that the Court made a restatement of the present legal situation in Europe, because Recital 16 also says: "The protection of other photographs should be left to national law", and that covers German non-creative "Lichtbilder", as well as "skill-and-labour" photographs in the UK which may or may not be considered as creative or the author's "own intellectual creations", whatever that means in a given context.

Despite the "kleine Münze" concept, author's rights countries struggled considerably to accommodate the protection of computer programs and databases. With these works an individual character or a stamp of the author can typically not be detected. The British "skill and labour" approach to originality could incorporate easily databases as compilations, ${ }^{128}$ and also computer programs could be, and were, ${ }^{129}$ regarded as being the product of sufficient skill, labour and effort to qualify

\footnotetext{
122 German Copyright Act 1965, Sec. 2(1)(5) (photographic work) and Sec. 2(2) (originality); Rehbinder (2010), p. 87.

123 German Copyright Act 1965, Sec. 72; Rehbinder (2010), p. 319.

124 German Copyright Act 1965, Sec. 2(1)(6) (cinematographic works, "Filmwerke"), Sec. 95 (mere films, "Laufbilder"); Rehbinder (2010), p. 118.

125 Since the law refers to the general rules for authorial photographic works for the determination of the scope of protection for mere photographs, the actual ambit of protection is difficult to ascertain; the yardstick is effectively the spirit of the protection rationale of neighbouring rights. Compare Rehbinder (2010), p. 298, for neighbouring rights in general. See also Vogel in: Schricker and Loewenheim (2010), Sec. 72 notes 10-11: the protection for mere "Lichtbilder" under the neighbouring right is not a case of "kleine Münze" protection of "Lichtbildwerke", but a separate category.

126 Rehbinder (2010), p. 87.

127 Painer, supra note 16, at paras. 85-88.

128 Independent Television Publications Ltd. v. Time Out Ltd. [1984] FSR 64. Bently and Sherman (2009), at discussing the originality rules of compilations and, separately, databases, p. 104, 108.

129 Sega Enterprises v. Richards [1983] FSR 73; Thrustcode v. W.W. Computing [1983] FSR 502. Both cases proceeded on the basis that computer programs were protected as literary works under the Copyright Act 1956. Both cases decided that point at interlocutory stage only. The Copyright (Computer Software) Amendment Act 1985 brought clarity and established copyright protection of computer programs as literary works.
} 
for protection. In Germany, computer programs initially did not normally get author's rights protection because the required standard of originality was typically too high. ${ }^{130}$ In France, the situation for computer programs became less problematic after the ruling in the Pachot case, ${ }^{131}$ which qualified the classical notion of originality in French law considerably, so that computer programs could be protected. $^{132}$

The principal idea of originality in droit d'auteur countries is not really compatible in most practical cases with the notion of the protection for computer programs and databases, which is essentially an investment protection. Rarely can such a product display sufficient genuine individuality of the author or can bear the stamp of the author's personality. If the courts find a personal intellectual creation in such works, it is - as is generally the case with the "kleine Münze" principleusually a normative finding, a definition of individuality or even creativity, not a finding of facts in the real world. The corresponding Software and Database Directives ensure that this normative finding is made across the EU in a harmonised form. It becomes obvious that these Directives encroached more on the traditional originality concepts in author's rights countries than on the idea of originality in the copyright system of the UK. At least one can say that the UK found it very easy to adapt to the "creativity" idea of the EU Directives. Consequently, scholars on the European Continent see the computer program ("imposed" by the Software Directive as literary work ${ }^{133}$ ) and the database as an alien element within the droit d'auteur system (as Michel Vivant said expressively about computer programs: "Logiciels: Et voici le loup dans la bergerie." ${ }^{134}$ ). The result of the Directives' requirement for a minimum standard of originality from which a national law must not depart, is the existence of two levels of originality in author's rights countries, one for computer programs, databases and photographs, and one for the other works that are so far not regulated by EU directives. The general opinion is that the originality requirement of "own intellectual creation" for Directive-regulated works is a lower standard than that of the traditional originality criterion in droit d'auteur countries, so the reverse to the classical UK situation. Some droit d'auteur commentators question whether it is desirable in the long run to maintain different originality levels within one jurisdiction, also in view of possible further harmonisation at EU level in the future. ${ }^{135}$ The EU "own intellectual creation" originality has also been interpreted as a qualitative shift from the subjective traditional "stamp of the author" originality to an objective approach to

\footnotetext{
130 Inkasso-Programm - German Federal Supreme Court, 9 May 1985, GRUR 1985, 1041: the Court did not rule out computer program protection in principle. See Loewenheim in: Schricker and Loewenheim (2010), Vor Secs. 69a et seq. note 3.

131 French Supreme Court, Cass. ass. plén., 7 mars 1986. On the implications of the interpretation of originality in this case for a potentially fluid and alternating understanding of the term "originality", see below under 5 .

132 Lucas and Lucas (2006), p. 80.

133 Directive 2009/24/EC, Art. 1(1). France CPI 1992, Art. L. 112-2 (13) (French Intellectual Property Code 1992), Germany: Sec. 2(1)(1) German Copyright Act 1965.

134 Vivant and Bruguière (2009), p. 177.

135 See the discussion of Germany in Loewenheim in: Schricker and Loewenheim (2010), Sec. 2 note 33.
} 
originality. ${ }^{136}$ This can be observed, for example, with regard to databases ("own intellectual creation") if these are compared with the originality criteria for anthologies and compilations, which the author's rights laws traditionally protected. ${ }^{137}$ The area of compilations and similar works was, however, always an established field of the operation of the "kleine Münze" concept. ${ }^{138}$ One can see that the introduction of the "own intellectual creation" criterion created as much fragmentation of the originality notion in droit d'auteur countries as in the UK. Between the dog of the "skill and labour" originality of copyright and the cat of the "personal intellectual creation" originality of the author's rights systems, the "own intellectual creation" originality of the EU Directives is something like a hyena, which zoologically belongs to the order of the cat-like carnivore but has rather doglike features. The discussion remains how one can establish what kind of animal it may be.

\section{The Same Wording of a Statute or EU-Directive in Different Legal Cultures: A Problem of Comparative Law}

A proper definition of the originality criterion of "own intellectual creation" has not yet been given, only approximations to this term have been attempted so far. In fact, this expression can be filled with the intellectual background of the legal culture in which it is applied. This is a phenomenon that is known to comparative lawyers in all areas of the law, and has been discussed particularly in the debates about the usefulness of a possible development and codification of a European Private Law in a European Civil Code. ${ }^{139}$ What happens if a legal rule, say, a rule embodied in a statute, is to be implemented in the context of another legal tradition or culture, or "transplanted"? A good example of this problem is the originality test of "own intellectual creation" of the EU Directives, although, unlike established rules of a foreign national law, it has a far less determinable content. Copyright and droit d'auteur lawyers alike may consider this rule as a "transplant" or being imposed on their national copyright/author's right system. The "own intellectual creation" originality rule may include copyright and droit d'auteur originality elements, but, as has been discussed, it neither belongs to the copyright nor the author's rights family. Such a malleable concept is particularly susceptible to being aligned to and incorporated into the legal tradition and mentalité of each distinctive European jurisdiction-rather contrary to the intention of harmonisation. This mentalité or cognitive approach to law is the method of thinking about the law, its understanding

\footnotetext{
136 Vivant and Bruguière (2009), p. 175 (photographs), 177 (computer programs).

137 See e.g. Lucas and Lucas (2006), p. 78-79; Vivant and Bruguière (2009), p. 179; Loewenheim in: Schricker and Loewenheim (2010), Sec. 4 notes 2, 5-6.

138 Loewenheim in: Schricker and Loewenheim (2010), Sec. 4 note 9.

139 E.g. Legrand (1997a), p. 44-63. This problem also emerges in relation to smaller sectors of European or constructed "European" private law, for example the European laws on suretyship: the laws in Europe are characterised by diversity and differentiation, and a uniform approach in EU legislation risks causing more legal fragmentation. Kenny (2007), p. 175, 191.
} 
of reasoning, its conceptualisation, systematisation and, generally, its epistemological construct. ${ }^{140}$ English common law, reflecting an English attitude in general, tends to feel uncomfortable with systematised rigid rules, while German law, here perhaps reflecting German inclinations, strives for structure, institutionalisation, comprehensive systematisation in clearly interpretable and predictable rules in form of statutes and codes. ${ }^{141}$ English law tends to be concrete, with much emphasis on the specific facts of a case, which are reported in detail, while civil law systems are interested in the abstract rule deduced from general propositions and sets of concrete cases, so that the individual facts fade. ${ }^{142}$ In the present context one can see that when looking at the originality definition for copyright in the statutes: English law has not got one ${ }^{143}$ and relies on case law and precedents according to its tradition. German law has a statutory rule, "personal intellectual creation". ${ }^{144}$ A look at German legal reality, however, reveals that this definition obtains meaning through case law only as well, ${ }^{145}$ so in effect the situation is not dissimilar to that in the UK. Nevertheless, the need was felt in Germany to give the courts a systematic skeleton on which they can grow their case law. English law rejects comprehensive codification in principle and would not see such a move as necessary. A similar case is that of laws against unfair competition (i.e. protection against free riding and other unfair business practices). Germany has such a statute, the "UWG" (Act Against Unfair Competition), ${ }^{146}$ while Britain is traditionally averse to an enactment of such a law, ${ }^{147}$ and relies on its common law, passing off in particular. However, the reality shows that in Germany unfair competition law under the Act Against Unfair Competition is also essentially case law resting on the delicate framework of fairly bland and general statutory provisions. If one exported the German Act Against Unfair Competition to the UK as a "legal transplant", then the UK courts would develop their own case law which may depart from the German courts considerably, although the legal approach to the implementation of this statute appears to be similar in both countries. The example of the German Act Against Unfair Competition is directly relevant here, because many works of "low level" originality under UK copyright law would be protected under the German Act. ${ }^{148}$ Rather than envisaging an "import" of a kind of Unfair Competition Act, for example in form of a EU Directive, law makers would probably be more successful if they relied on non-legislative harmonisation through judicial convergence, so that,

\footnotetext{
140 Legrand (1997a), p. 45.

141 Lawson (1977), 53, 80-81.

142 See discussion and examples in Legrand (1997a), p. 47-50.

143 Compare CDPA 1988, Secs. 1(1)(a) and 3 and 4.

144 German Copyright Act 1965, Sec. 2(2).

145 Loewenheim in: Schricker and Loewenheim (2010), "Einleitung", note 6.

146 Act Against Unfair Competition 2012 (Gesetz gegen den unlauteren Wettbewerb (UWG)).

147 Cornish (2004), p. 80.

148 Loewenheim in: Schricker and Loewenheim (2010), Sec. 4 note 35 (here in relation to databases). This applies in particular to works which do not pass the higher originality standard for author's rights protection in Germany.
} 
more in line with a common law philosophy, the courts would achieve the same results regardless of the norms or procedures they apply. ${ }^{149}$

The "transplant" or borrowing of norms, either single rules or whole bodies of law and their intrinsic systematisation, has always happened in history. Borrowing was the most powerful means to bring about changes in a given system. Legal transplants operate in the tension between the culture and tradition of a people as the law (apparently) embodies them, and the fact that rules from a different system and culture have been received and incorporated by another tradition: the reception of Roman law in Western Europe is historically the most important example of this process. ${ }^{150}$ Transplantation of foreign norms is nevertheless problematic: ${ }^{151}$ the outcome of such transplantation depends on the political factors and the socioeconomic circumstances of the receiving country. The role of the legal profession and the judiciary, and the way in which these interact and conduct court trials (e.g. inquisitorial or accusatorial method) is obviously extremely important in this assimilation process of imported rules. The same must be said about the constitutional distribution between the judicial and administrative powers, their interrelation with (non-governmental) social groups, and the legislation which the bodies endowed with these powers make or enforce. ${ }^{152}$

The receiving country will reshape the transplanted norm through partial acceptance and reinterpretation according to their legal culture. This reshaping and reinterpretation is a hermeneutic process of "understanding", what Gadamer called Vorverständnis or "pre-understanding". ${ }^{153}$ Especially the German jurist Josef Esser applied this concept to law. ${ }^{154}$ Lawyers would understand and analyse a norm from a different legal culture based on assumptions that are rooted in the familiarity of their own legal system. One can test this hypothesis by looking at the understanding of "originality" in copyright, and particularly the "own intellectual creation" formula in the EU Directives for the definition of originality in the respective national laws. In France, this process started even before the advent of the Software Directive, when the French Supreme Court in Pachot ${ }^{155}$ was confronted with the conundrum of giving protection to computer programs and reconciling this with the general originality principle in French author's rights law. Strictly speaking, this judgment (delivered in 1986) was not a transplantation of a EU rule at the time but the incorporation of a statutory amendment to French author's rights law that conflicted with the general understanding of author's rights protection in France up

\footnotetext{
149 This is suggested by Kenny (2007), p. 196, for the harmonisation of suretyship in Europe, but is equally relevant in the present context.

150 Watson (1974), p. 21, 95 et passim.

151 Collins (1991), p. 396, 397-398.

152 Kahn-Freund (1974), p. 7-8, 12, 17-18. Alan Watson is more optimistic about the transplantation of legal rules, e.g. Watson (1974), p. 95-96: “... legal rules move easily and are accepted into the system without too great difficulty. This is even so when the rules come from a very different kind of system." A rejection tout court of legal transplants by Legrand (1997b), p. 111.

153 Gadamer (2003), p. 269-271, 275-277, 293-295.

154 Whitman (2003), p. 325-326.

155 French Supreme Court, Cass. ass. plén., 7 mars 1986, note by A. Lucas in 3/1986 RIDA (Revue internationale du droit d'auteur), p. 136.
} 
to then. In 1985, this amendment (in the spirit of Anglo-American legal culture of protection) added computer programs to the list of author's rights protected works but did not set out specifically how originality was supposed to be defined for these works. In Pachot, the Court reinterpreted the classical formula of originality"l'empreinte de la personnalité de l'auteur"—as "la marque d'un apport intellectual de l'auteur" (a mark of intellectual contribution of the author). ${ }^{156}$ The subjective aspect of personality of the author reflected in the work (in the sense of Flaubert's "Madame Bovary, c'est moi") has been replaced by the objective idea of intellectual input of a person: it is effectively the choice, selection and arrangement of a person that makes the work original, not the specific nature of the author's personality that has shaped and individualised the work. ${ }^{157}$ That applies to all works (at least where they are covered by the Directives). The French Vorverständnis of the idea of originality as "stamp of the author" is the basis for moulding an originality concept that is supposed to apply to computer programs, too. But rather than giving up the old originality idea and replacing it with a sui generis definition, the legal tradition has been used to shape and justify an essentially new concept. The term "own intellectual creation" in the EU Directives invites an interpretation of just that kind, and the CJEU has reiterated that idea in Infopaq, ${ }^{158}$ Painer $^{159}$ and Football Dataco. ${ }^{160}$ It reflects, incidentally, very much "skill and labour" originality thinking of the UK and the US, for example with regard to compilations. ${ }^{161}$ When the CJEU stresses in Infopaq ${ }^{162}$ that "only through the choice, sequence and combination of ... words" the author may express his originality and creativity and so produces an intellectual creation, this means that in the eyes of the law a compilation is not a novel, but a novel is a compilation of words. One can also see the difference between the "own intellectual creation" formula and the statutory definition of originality in Germany as "personal intellectual creation" which asks for a personal, subjective originality approach in principle. But to avoid the consequent application of such a subjective test and to maintain conformity with the Software Directive, the German Copyright Act prohibits any qualitative or aesthetic criteria for the assessment of originality of computer programs. Nevertheless, German commentators insist that the computer program must be a work shaped by the individual spirit of the creator to qualify for protection. ${ }^{163}$ This individuality can in effect only be notional, because qualitative and aesthetic criteria are the typical-and subjective (that is: referring to the

\footnotetext{
156 Lucas and Lucas (2006), p. 80-81.

157 Vivant and Bruguière (2009), p. 178.

158 Infopaq, supra note 1 , at para. 45.

159 Painer, supra note 16, at para. 92.

160 Football Dataco, supra note 2, at especially para. 48.

161 UK: Independent Television Publications Ltd. v. Time Out Ltd. [1984] FSR 64; Football League Ltd v. Littlewoods Pools Ltd. [1959] Ch. 637. In the US, Feist, supra note 72, in itself is the model case on this point.

162 Infopaq, supra note 1, at para. 45.

163 Section 60(a)(3) German Copyright Act 1965. Loewenheim in: Loewenheim and Schricker (2010), Sec. 69(a), notes 17, 19.
} 
author)-hallmarks of individuality. But it shows how the incorporation of a "transplanted" norm works (in France it was arguably a "pre-emptive" transplant). A juristic Vorverständnis or pre-understanding of originality in the receiving jurisdiction becomes projected on the imported norm and so the norm becomes incorporated into the existing body of law. However, according to some French commentators, the alignment of computer-program originality with the originality concept in general has failed. ${ }^{164}$ But it has also been said that the integration of computer programs in the general French droit d'auteur system only showed the adaptability of the droit d'auteur system to new intellectual goods. For computer programs, originality can be located in two stages, the source code (which is, so is argued, not a different situation from assessing the originality of a musical composition), and the interface between man and machine. Every computer programmer has his own style engendered by the choices he makes in the programming process, and so he stamps his personality on his work. ${ }^{165}$ According to this view, the transplant seems to have succeeded.

The element of choice as a constituent element for creative originality is not new to author's rights systems and not confined to the "new works", like computer programs or databases. Choices among versions of selection and arrangement play an important role for the determination of originality of derivative works, ${ }^{166}$ especially when these derivative works are restorations of older works of art. Restorations stand against the notion of creative originality or novelty as an artist would see it. The restorer tries to reconstruct and recreate the work in the spirit and style of the initial author and will therefore avoid deliberately any personal innovative or creative input. But for copyright purposes, derivative works, also restorations, are still original and protected if there is some space for an intervening act of the restorer's skill and labour, so that the restored work differs sufficiently from the pre-existing work. ${ }^{167}$ This difference is the result of the restorer's personal input of "skill, labour and judgement", as a UK copyright lawyer would say, ${ }^{168}$ or the result of the restorer's creative choices she made in relation to the selection and arrangement of the techniques and restoration decisions deployed in the restoration, a choice that enabled the author-restorer to stamp her "personal touch" on the restoration, to use the words of the CJEU. ${ }^{169}$ How much the interpretation of the CJEU is really in the spirit of author's rights originality concepts is unclear, as has been shown. Furthermore, the individuality and personality of a human being that is to reflect in his/her work, can arguably not be simplified to just an ability to make (perhaps informed and educated) choices; this is a reductive economic market model of humans as mere producers and consumers, but it may well be part of the

\footnotetext{
164 So certainly Vivant and Bruguière (2009), p. 177-178. Also Lucas and Lucas (2006), p. 81-82, 96.

165 Binctin (2010), p. 60.

166 For the UK, see e.g. Interlego v. Tyco Industries Inc. [1988] RPC 343.

167 Rahmatian (2010), p. 60-61.

168 This is especially based on Interlego v. Tyco Industries Inc. [1988] RPC 343, at 371-372: the derivative work must have some additional element of (qualitatively even small) material alteration or embellishment which would then suffice to make the totality of the work an original work.

169 Painer, supra note 16, at para. 92, Football Dataco, supra note 2, at para. 38.
} 
mind-set of EU institutions, including the CJEU. However, most of the restoration cases within the visual arts do come from the author's rights countries France and Italy. Protection is usually granted in these countries, because the restorer is regarded as having sufficient flexibility ("choice") in the restoration process so as to leave enough space for some personal input, and the individuality and spirit of the creator is expressed in the work. ${ }^{170}$ A particularly interesting decision is Sawkins, ${ }^{171}$ a case involving the restoration of musical works of the Baroque era. At issue was whether there is copyright protection for the performing editions the claimant prepared by using scattered manuscripts and by inserting and recomposing missing material. ${ }^{172}$ Relevant is here that the case has been decided in England and in France on substantially the same facts, ${ }^{173}$ and in both countries the courts gave the claimant copyright/author's rights protection in relation to his performing edition (obviously not in relation to the music which is in the public domain). ${ }^{174}$ While the English court could rely on its classical "skill and labour" originality doctrine, ${ }^{175}$ and the principle that copyright protection seeks to prevent making a short cut, ${ }^{176}$ the French court stressed that originality is a relative concept and found no difficulty in attesting the restorer a personal contribution that amounts to genuine creative work. A work is original if (following Pachot) it has the mark of intellectual contribution. The element of choice played a role in the assessment of the originality of the intellectual contribution. ${ }^{177}$

A case of a "transplant" into UK law of the "own intellectual creation" originality rule of the EU Directives and its interpretation by the CJEU is the English case of Meltwater. ${ }^{178}$ The High Court, affirmed by the Court of Appeal, held that the defendant's copying of titles and short extracts of newspaper articles as part of its business as a commercial media monitoring service could infringe copyright. When assessing the relevance of the Infopaq decision, the High Court found that the CJEU in Infopaq only restated the originality test but did not alter it. If the text extract taken amounts to an expression of the intellectual creation of the author (test of quality instead of test of substantiality, i.e. the taking of a substantial

\footnotetext{
170 France: Lucas and Lucas (2006), p. 118. See discussion with case examples by Ginsburg (2002-2003), p. 1063, 1083-84; Rahmatian (2010), p. 64-66. For Germany, see discussion relevant to restorations by Loewenheim in: Schricker and Loewenheim (2010), Sec. 3 notes 9, 33.

171 In the UK: Sawkins v. Hyperion [2005] EWCA Civ 565, [2005] RPC 32.

172 The case has been discussed at length by Rahmatian (2009), at 560-591.

173 Sawkins v. Harmonia Mundi, TGI Nanterre, $1^{\text {re }}$ ch. 19 Janv. 2005: 1/2006 RIDA. 391. See also, "Case Comment: Sawkins v. Harmonia Mundi" (2006) IIC 118-119.

174 French textbooks refer to the UK case as the parallel and equivalent case to the French decision, see Lucas and Lucas (2006), p. 123.

175 Sawkins v. Hyperion [2005] EWCA Civ 565, para. 36.

176 Sawkins v. Hyperion [2005] EWCA Civ 565, para. 87.

177 Sawkins v. Harmonia Mundi, supra note 172, at 19 Jan. 2005, at 4-5: "une œuvre de l'esprit doit porter la marque de l'apport intellectuel et personnel de l'auteur, peu important son degré d'originalité ... [le demandeur] a dû procéder à des choix artistiques personnels et arbitraires à partir de son interprétation personnelle des cuvres ... l'originalité était relative, il importe peu que les apports soient disséminés ..." (my emphasis).

178 Newspaper Licensing Agency Ltd. and others v. Meltwater Holding BV and others [2010] EWHC 3099 (Ch), and before the Court of Appeal, [2011] EWCA 890 Civ, [2012] RPC 1.
} 
part), copyright subsistence and infringement is possible. ${ }^{179}$ The Court of Appeal held that "intellectual creation", as referred to by the CJEU, relates to the question of origin, not novelty or merit; therefore, Infopaq did not qualify the long-standing originality test of the classical English cases such as University of London Press and Ladbroke. ${ }^{180}$ This minimalist approach to the impact of Infopaq on UK copyright law attracted criticism. There are unquestionably problems with Meltwater, such as the potentially perilous consequences on freedom of expression generally if protection were given to titles of newspaper articles. ${ }^{181}$ This concern is valid as such. However, this issue is not one of originality but of permitted acts in the context of infringement: especially in the Anglo-Saxon world there is the persistent belief, Lockean in origin and unfortunate, that if property or copyright-property is established, it must be unassailable. It is nothing of that sort. Instead of trying to readjust the already opaque originality requirement, it would be more appropriate to have generous and much broader permitted acts, and a better understanding of necessarily overriding constitutional rights, such as freedom of expression or freedom of the arts, which may relegate the copyright owner to the second place. ${ }^{182}$

In any case, the Meltwater decision is an indicator of the way in which UK courts may digest the "transplant" of an "own intellectual creation" originality test. In contrast to Meltwater, one cannot regard the classical English cases on originality without any qualifications at all after Infopaq and the subsequent cases of the CJEU, ${ }^{183}$ but it is also overstated to declare them as overruled altogether. ${ }^{184}$ Furthermore, one can imagine what would happen if an EU copyright code were enacted. ${ }^{185}$ The whole development of the gradual incorporation or transplantation of EU originality rules, as shown before, would repeat itself, unless this process were already completed and the originality rule in a future comprehensive EU Copyright Directive would only be a restatement of the status quo. The draft European Copyright Code proposed by the Wittem Group in 2010, defines in Art. 1.1(1) subsistence of copyright in a work which "constitutes its author's own intellectual creation", ${ }^{186}$ following the EU Directives. The note to Art. 1.1(1) suggests, however, that we have not arrived at an uncontested status quo yet,

\footnotetext{
179 Meltwater (High Court), supra note 178, at paras. 75-81.

180 Meltwater (Court of Appeal), supra note 178, at paras. 19-20.

181 "Bently slams "very disappointing" ruling in Meltwater", IPKAT, 27 July 2011, available at: http://ipkitten.blogspot.co.uk/2011/07/bently-slams-very-disappointing-ruling.html (accessed on 18 April 2012).

182 So, for example, in Germany: Wild in: Loewenheim and Schricker (2010), Sec. 97 note 35 in relation to Art. 5 (freedom of expression, freedom of the arts and sciences) of the German Constitution (Grundgesetz).

183 On the possible further development of the originality requirement, see below under 6 in the conclusions.

184 So, however, Derclaye (2010), p. 249-250.

185 See discussion on such a copyright code in Cook and Derclaye (2011), p. 259-269.

186 Chapter 1 (Works), Art. 1.1(1). Wittem International Network Project on a European Copyright Code, available at: http://www.copyrightcode.eu/ (accessed 18 April 2012).
} 
because the proposed originality definition seems to accommodate "skill and labour" originality as well as "creative" originality. ${ }^{187}$

In essence, determining the content of the "own intellectual creation" formula or of any other definition of originality is philosophically an exercise in nominalisma discussion about abstract entities as a metalinguistic discourse. One cannot expect anything else. As copyright is conceptually dematerialised property without an existence in the real world, ${ }^{188}$ created exclusively by legal norms, that is, words, the definition of originality as one constituting an element of this purely conceptual entity cannot be ascertained by reference to determinable facts and physical entities in the material world. Originality is a definition resting on further definitions, and all are equally valid in principle. Or, in the more popular rendering of Lewis Carroll's Humpty Dumpty: ${ }^{189}$ " "When I use a word,' Humpty Dumpty said, in rather a scornful tone, "it means just what I choose it to mean-neither more nor less", 190 One can now conjecture what the UK courts may choose "originality" to mean in the light of the recent CJEU decisions.

\section{Conclusion: The Possible Future Development of the Originality Requirement in UK Copyright Law}

The recent CJEU decisions on originality within copyright in the EU, Infopaq, Bezpečnostní softwarová asociace, Painer and Football Dataco, have arguably not upset either the existing systems of copyright in the UK or of author's rights laws in continental Europe. ${ }^{191}$ In relation to the "author's own intellectual creation" formula as the test for originality, as can be found in the corresponding EU Directives, the CJEU restated the law in the way in which it has already developed through court decisions and jurisprudence in the Member States. This is certainly true of the types of work which the Directives address (computer programs, data bases and photographs) and seems to be an example of primarily non-legislative harmonisation through judicial convergence, based on different protection philosophies as their starting point. ${ }^{192}$ The regulation of these categories of work has led to different standards of originality within the respective national systems in both the copyright and the author's rights countries. It is not entirely clear if the CJEU has extended the "own intellectual creation" test beyond this small circle of works

\footnotetext{
187 Chapter 1 (Works), note 7 to Art. 1.1.(1): “The term 'the author's own intellectual creation' ... can be interpreted as the 'average' European threshold, presuming it is set somewhat higher than skill and labour. This is possible if emphasis is put on the element of creation. For factual and functional works, the focus will be more on a certain level of skill (judgement) and labour, whereas for productions in the artistic field the focus will be more on personal expression.".

188 Rahmatian (2011), p. 12-25, on the concept of copyright as dematerialised property.

189 It has found its way into a House of Lords decision in a different context, in Lord Atkin's dissenting speech in Liversidge v. Anderson [1942] AC 206, HL, at 245.

190 Carroll (1970), 269.

191 So also the view of Professeur Michel Vivant, Sciences Po, Paris, in an email correspondence with the author, 10 April 2012. I am most grateful to Professeur Vivant for letting me have his views.

192 Compare Kenny (2007), p. 196, and above under 5.
} 
and has sought to apply this originality requirement to all copyright works in form of an originality test that is standardised EU-wide. Some statements in Infopaq suggest this ${ }^{193}$ (followed especially by Football Dataco ${ }^{194}$ ), and this view also finds support in the CJEU's attempt at broadening the meaning of the special provision of Art. 2(a) of the Information Society Directive as a tenuous statutory basis for a general EU wide originality test. ${ }^{195}$ If the CJEU has indeed developed such a general originality test across all areas of copyright, it has arguably acted beyond its assigned powers, but even then the effect on the national laws would be limited. The CJEU leaves the concrete application of its perhaps modified originality test to the national courts of the Member States, ${ }^{196}$ so these have sufficient leeway when they incorporate this "legal transplant" into their own copyright/author's rights traditions.

For the UK that would mean that the old "skill and labour" originality requirement has to be qualified somewhat in theory; although, the practical difference that the application of this new originality test will make to the UK copyright system is probably very small indeed. The Meltwater approach (that is, there is no change at all as a result of Infopaq ${ }^{197}$ ) is too simplistic and an unsatisfactory starting point. It is more appropriate to reshape slightly the classical originality definition of UK copyright law of "a work is original if it is the product of its author's own skill, labour and judgement", a rather simplifying aphorism anyway, and to concentrate on the element of "judgement". The author must apply her judgement to make selections and choices when she creates the work, and through these choices the author expresses original creative ability and thus stamps her personal touch: in this way the result will be an intellectual creation. This interpretation certainly complies with the CJEU rulings. ${ }^{198}$ One could restate the originality requirement in UK copyright law in the following way: a creation is protected by copyright if it constitutes an original work that is recorded in some permanent form. Originality means that a sufficient amount of skill, labour and judgement has gone into the work in such a way that through the choices, selection and arrangement in the making of the work the author gives the work a modicum of individuality and so renders it his/her own intellectual creation.

The suggested approach is akin to the one particularly for derivative works in the $\mathrm{UK}^{199}$ and to the spirit of Feist in the US (a case which abandoned the simple "sweat of the brow" approach but did otherwise not constitute a paradigm shift in US copyright law). According to Feist, highly personal choice is not required; if

\footnotetext{
193 Infopaq, supra note 1, at para. 27.

194 Football Dataco, supra note 2, at paras. 37-38.

195 Infopaq, supra note 1, at paras. 33 and 43; Painer, supra note 16, at paras. 90 and 95.

196 Infopaq, supra note 1, at para. 51; Painer, supra note 16, at para. 94, Bezpečnostní, supra note 15, at para. 47; Football Dataco, supra note 2, at para. 43. This is in accordance with Art. 267 (ex 234) TEU; see also Broberg and Fenger (2010), p. 156.

197 Meltwater (Court of Appeal), supra note 178, at paras. 19-20.

198 Infopaq, supra note 1, at para. 45; Painer, supra note 16, at para. 94; Football Dataco, supra note 2 , at para. 38 .

199 Compare Interlego A.G. v. Tyco Industries Inc. [1988] RPC 343 at 371-372.
} 
thoughtful evaluation and choice can be shown, that satisfies the originality test. ${ }^{200}$ This choice in the selection and arrangement (in a broad sense) has a personal element, in that it depends (to some extent at least) on the individual's personality in which way the choice is made. The choices confer on the work individuality and make it the author's own intellectual creation. Often the author's activity in this regard is then named as "creative". This is in line with the currently common broad meaning of "creativity" 201 that emerged in the 1960s; before, the word "creativity" was rather used to denote artistic creativity. Today also marketing strategies, business models and educational methods are often referred to as "creative". But one should not be fooled by such ubiquitous "creativity" rhetoric. This has usually nothing to do with the creativity of an artist or a scientist. ${ }^{202}$ Their creativity reveals itself, very generally, in expressions that enable humans to perceive and interpret the world and all its manifestations significantly differently from before. The artist or scientist also creates a world on its own, and that is the same whether it is a world of sounds, colours, words or mathematical definitions and proofs. It is no surprise that historically the Church could not accept the artist-author as a creator because this idea would have challenged the religious concept of God as the only creator of a world. $^{203}$ Nowadays, as the all-encompassing efficient market seems to have replaced God's world order, ${ }^{204}$ the unpredictable and uncontrollable author-creator has been explained away as an artificial "romantic" figment by "death of the author" ideologies on a shaky postmodernist foundation: ${ }^{205}$ this is certainly in the interest of the management systems of the "creative industries". ${ }^{206}$ Copyright laws are little concerned about high artistic creativity, and author's rights laws are less concerned about it than appears at first glance. The meaning of "originality" has been ascertained mostly through court cases in which entirely mundane works were at issue. Understandably, because in commercial reality it is principally this idea of business products that copyright is supposed to serve. It protects and encapsulates these works as property for the purpose of capital investment, also "human capital" investment, and speculation.

Therefore, even if, notionally, the originality threshold has been raised slightly in the UK as a result of the CJEU rulings, one can still presume that in the great majority of cases works would also gain protection under the new regime.

\footnotetext{
200 Ginsburg (1992), p. 345.

201 Hudson (1970), p. 218; Kristeller (1983), p. 105, 108.

202 The separation of the arts from the sciences which established itself in the early nineteenth century, was unknown to the Renaissance (if one could called the sciences thus then), see e.g. Hale (1971), p. 311. The strong link between the arts and the sciences in the sixteenth to the eighteenth centuries doubtlessly fostered creativity in both areas.

203 May (1994), p. 73-74; Rahmatian (2011), p. 160-163, with further references.

204 Supiot (2007), p. 64-67; Legendre (2007), p. 21, 33, 54, 60.

205 Especially Barthes (1979), p. 142-148. It remains debatable if and to what extent Barthes can be blamed for the way in which his seminal text has been used as an argumentative basis by future authors or "scriptors" of the "Romantic author" critique.

206 Extensive refutation of the "romantic author" arguments in copyright scholarship in Rahmatian (2011), p. 149-182.
} 
Borderline cases, such as Graves' Case $^{207}$ for photographs and Walter v. Lane ${ }^{208}$ for literary works, would finally disappear, and that is no loss at all. However, one should not fall into the trap of celebrating a slightly disingenuous victory over these cases. It would be a scurrilous situation if the "pedestrian" approach to originality in the UK were given up under a wrongly understood regime change as apparently imposed by the CJEU, and banal photographs were no longer protected, while, for example, in Germany, a droit d'auteur country with generally a more demanding originality standard, commonplace photographs may very well obtain protection. In Germany, an artistic photograph is protected as a droit d'auteur work, ${ }^{209}$ a photograph with some limited creative input is also protected as a droit d'auteur work under the "kleine Münze" principle, ${ }^{210}$ a commonplace photograph obtains protection under a neighbouring right, ${ }^{211}$ and in some contexts there is still protection for photographs of all kinds under the German Act Against Unfair Competition. ${ }^{212}$ As far as Walter v. Lane is concerned, the facts of this case would be a rare scenario today. No reporter would nowadays make a written transcript of a speech but switch on a tape recorder instead. ${ }^{213}$ Then, of course, the reporter would unquestionably obtain copyright protection in the sound recording, which is not even subject to the low "skill and labour" originality standard for authorial works, ${ }^{214}$ and that curiously does not seem to be controversial.

A utopian perspective would like to separate the truly artistic creations from the commonplace works and would protect only the former under author's rights law with a relatively high originality standard. The practical and commonplace works would be protected under a neighbouring right to ensure investment protection and prevention of free riding and of a short cut by competitors. However, this protection would be much more limited in time (10-25 years) to enable the investor to recoup his expenses and make a profit, but not more than that. However, recent legislative developments at the European level point clearly in the opposite direction. There is no reason to assume that the CJEU has departed from this trend. The CJEU cases may cause a limited adjustment to originality in UK copyright law, but it will not be a seismic shift.

\footnotetext{
207 Graves' Case (1869) LR 4 QB 715.

208 Walter v. Lane [1900] AC 539. This case would no longer be relevant in relation to the protection of works under these specific facts (verbatim written transcript of a speech: that would now definitely no longer obtain protection), but the principles of originality established in this case will largely remain valid, especially that "originality" does not mean artistic creativity or novelty, and that copyright protection has at its heart the prevention of a short cut.

209 Section 2(1)(5) German Copyright Act 1965.

210 Loewenheim in: Loewenheim and Schricker (2010), Sec. 2 note 182, 184.

211 Section 72 German Copyright Act 1965.

212 E.g. under Sec. 4(9) German Copyright Act, see Vogel in: Schricker and Loewenheim (2010), Sec. 72 notes 28,53 . On that basis, photographs in, or as, commonplace works may be protected. Theoretically, the UK CDPA 1988 could be amended to cover safely commonplace photographs in the future, but, according to the argumentation, at such a move would be unnecessary.

213 Gravells (2007), p. 291.

214 CDPA 1988, Sec. 5A(2).
} 
Acknowledgments I am most grateful to Professor Graeme Dinwoodie, University of Oxford, Mr Jonathan Griffith, Professor Adrian Sterling, Professor Uma Suthersanen, all three Queen Mary, University of London, and Professor Charlotte Waelde, University of Exeter, for their comments on an earlier draft which improved the final version significantly. However, responsibility for errors rests with the author. I am also very grateful to Professeur Michel Vivant, Sciences Po, Paris, for letting me have his views in an email response in relation to the likely impact of the recent CJEU decisions on the understanding of originality in European copyright laws.

\section{References}

Arnold R (1999) Case comment: Are performers authors? EIPR 21(9):464-469

Barthes R (1979) The death of the author. In: Heath S (ed) Image-music-text. Fontana/Collins, Glasgow, p 142-148

Bently L, Sherman B (2009) Intellectual property law, 3rd edn. Oxford University Press, Oxford

Binctin N (2010) Droit de la propriété intellectuelle. Lextensio Éditions, Paris

Broberg M, Fenger N (2010) Preliminary references to the European Court of Justice. Oxford University Press, Oxford

Carroll L (1970) Through the looking glass and what Alice found there, Chap. 6. In: The annotated Alice (introduction and notes by M. Gardner). Penguin, London, p 269ff

Collins H (1991) Methods and aims of comparative contract law. OJLS 11(3):396ff

Cook T, Derclaye E (2011) An EU Copyright Code: what and how, if ever? IPQ 3:259-269

Cornish WR (1989) Moral rights under the 1988 Act. EIPR 11(12):449ff

Cornish WR (2004) Intellectual property: Omnipresent, distracting, irrelevant? Oxford University Press. Oxford

Derclaye E (2010) Case comment: Infopaq International A/S v Danske Dagblades Forening (C-5/08): wonderful or worrisome? The impact of the ECJ ruling in Infopaq on UK copyright law. EIPR 32(5):247-251

Derclaye E (2012) Football Dataco: skill and labour is dead! in: Kluwer Copyright Blog, 1 March 2012. http://kluwercopyrightblog.com/2012/03/01/football-dataco-skill-and-labour-is-dead/. Accessed 15 March 2012

Gadamer HG (2003) Truth and method. In: Weinsheimer J, Marshall DG (eds) 2nd edn. Continuum, New York, pp 269ff

Ginsburg JC (1992) No 'Sweat?' copyright and other protection of works of information after Feist v. Rural Telephone. Columbia Law Review 92:338-388

Ginsburg JC (2002-2003) The concept of authorship in comparative copyright law. DePaul Law Review 52:1063

Gravells NP (2007) Authorship and originality: the persistent influence of Walter v. Lane. IPQ 3:267ff

Hale JR (1971) Renaissance Europe 1480-1520. Collins, London

Hegel GWF (1991) Elements of the philosophy of right. In: Wood AW (ed), Nisbet HB (trans). Cambridge University Press, Cambridge, p. $95 \mathrm{ff}$

Hudson L (1970) The question of creativity. In: Vernon PE (ed) Creativity: selected readings. Penguin Books, Harmondsworth, p 217-234

Kahn-Freund O (1974) On uses and misuses of comparative law. MLR 37(1):7ff

Kant I (1785) Von der Unrechtmäßigkeit des Büchernachdrucks. Berliner Monatsschrift 5:403-417. http://www.copyrighthistory.org. Accessed 7 April 2012

Kenny M (2007) Standing surety in Europe: Common core or tower of Babel. MLR 70(2):175ff

Kristeller PO (1983) "Creativity" and "tradition". J History Ideas 44(1):105ff

Lawson FH (1977) A common lawyer looks at the civil law, vol 53. Greenwood Press, Westport

Lee YH (2012) Case comment: Painer v. Standard Verlags GmbH, Axel Springer AG. EIPR 34(2):290ff

Legendre P (2007) Dominium Mundi: l'empire du management. Mille et une nuits, Paris, p 21ff

Legrand P (1997a) Against a European civil code. MLR 60(1):44-63

Legrand P (1997b) The impossibility of legal transplants. Maastricht Journal of European and Comparative Law 4:111

Locke J (1960 [1690]) The second treatise of government. In: Laslett P (ed) Two treatises of government. Cambridge University Press, New York

Lucas A, Lucas H-J (2006) Traité de la propriété littéraire et artistique. 3rd edn. Litec/Lexis-Nexis, Paris 
May G (1994) Creatio ex nihilo: the doctrine of "Creation out of Nothing" in early Christian thought. Worall AS (ed), T\&T Clark, Edinburgh

Pila J (2008) An intentional view of the copyright work. MLR 71(4):535ff

Rahmatian A (2009) The concepts of 'Musical Work' and 'Originality' in UK copyright law-Sawkins v. Hyperion as a test case. IIC 40:560ff

Rahmatian A (2010) Copyright protection for the restoration, reconstruction and digitization of public domain works. In: Derclage E (ed), Copyright and cultural heritage. Edward Elgar, Cheltenham, p $51-76$

Rahmatian A (2011) Copyright and creativity. The making of property rights in creative works. Edward Elgar, Cheltenham

Rehbinder M (2010) Urheberrecht. 16th edn. C.H. Beck, München

Ricketson S, Ginsburg JC (2005) International copyright and neighbouring rights. The Berne Convention and beyond. 2nd edn. vol. 1. Oxford University Press, Oxford

Rigamonti CP (2006) Deconstructing moral rights. Harvard International Law Journal 47(2):353ff

Rosati E (2010) Originality in US and UK copyright experiences as a springboard for an EU-wide reform debate. IIC 41(5):524ff

Schricker G, Loewenheim U (eds) (2010) Urheberrecht. Kommentar. C.H. Beck, München

Supiot A (2007) Homo juridicus. On the anthropological function of the law. Verso, London

Vivant M, Bruguière J-M (2009) Droit d'auteur. Dalloz, Paris

Watson A (1974) Legal transplants: an approach to comparative law. Scottish Academic Press, Edinburgh

Whitman JQ (2003) The neo-romantic turn. In: Legrand P, Munday R (eds) Comparative legal studies: traditions and transitions. Cambridge University Press, Cambridge, p 312-344 